\title{
Surreally Human: Jan Švankmajer's World of Self-Destructive Puppets
}

Jan Švankmajer's work is the bearer of a magic function, revealing the marvellous through mystification. Švankmajer, like the alchemists of old, is continually distilling the water of his experiences so that through this process, the heavy water of knowledge, essential for the transmutation of life, begins to flow.

In his work, Švankmajer constantly explores and analyses his concern with power, freedom, human desire, fear and anxiety, his interest in confrontation, alienation and destruction, his fascination with experiment, alchemy, magic, transformation, reality and unreality, his obsession with games and breaking rules, as well as his attraction in the surface materiality of things, the texture and the physical properties of objects, creating films that are highly visual and strikingly theatrical, saturated by cruel melancholy and black humour. His oeuvre is a poetic and dynamic work that operates by means of close interactions with literature, theatre, and the visual arts. This approach consistently rejects conventional critical categorisation, spilling over forcibly into various forms of representation; it ruptures dominant cinematic conventions, and it rejects and exceeds normative barriers in filmic expression.

Although in many ways recognisably included in the rich tradition of East European animation, Švankmajer tends to distance himself from the Czech animation school, refusing to limit himself to the generic idea of 'animation' and standing apart by virtue of his eclecticism and passionate commitment to 'militant Surrealism'. Švankmajer's work remains unique as a result of the way he combines, blends and transforms disparate elements, as 'an alchemist of the Surreal'. Various elements of his work are deployed in the service of fantasia, such as stop-frame animation, trick photography, the manipulation 
of marionettes, puppets, three-dimensional modelling, collage and live action; from these means he produces an aesthetically rich and technically brilliant overall effect as well as an intellectually challenging creation.

Jan Švankmajer joined the Czech Surrealist group based in Prague in 1970, after meeting its leader and most prominent theoretician, Vratislav Effenberger. The contemporary Surrealist group stresses its collective base, showing a concern for mutual or group activity, which leads to collective artistic adventures, rejecting the autonomy of the artist and also sustenance of an interest in debate and discussion. The group also encourages the use of destruction as a creative means to assault rationality, the conception of experiment as discovery, and the objectification of the hidden. Emphasis is also given by this group to Surrealism as a world-view, stressing the links with international Surrealism. Furthermore, the contemporary Surrealist group centres its activities around study of the imaginary, showing an on-going association with Teiges ${ }^{1}$ ideas and dream analysis, with Surrealists conceiving the imagination as based on a notion of psychic automatism and the unconscious subject. The historical contingency of a Surrealist movement, surviving in Czechoslovakia, almost cut off from its mainstream, based in Paris, but that had long-since lost its force, gives Švankmajer's work an individuality that makes his particular version of Surrealism a complex matter.

Švankmajer's experimentation with Czech Informal Art, a Czech form of Abstract Expressionism, was no more than a starting point in his artistic quest, but the art style's textural emphasis is reflected in his later work. Švankmajer's roots in Czech experimental theatre, in puppetry and Fine Arts are clearly more significant and evident in his films than those that can be detected in contemporaneous cinema, even though the interaction between cinema and the experimental traditions in theatre, literature and the visual arts has generally been quite persistent in Czech culture (DONALD 1989). However, Švankmajer acknowledges certain cinematic influences, such as Soviet avant-garde film, namely Sergei Eisenstein (from whom he takes the concept of montage as a sequence of shocks that may be the inspiration for the bold juxtapositions and staccato rhythms characteristic of Švankmajer's editing), and Dziga Vertov (for the cinematic experimentations in the conveyance of visual phenomena in his films). Švankmajer also acknowledges theatrical influences in his work, particularly Vsevolod Meyerhold (who was a fervent advocate of Symbolism in theatre), Alexander Tairov, the father of the Synthetic Theatre, and Oskar Schlemmer, a Master of Form at the Bauhaus theatre workshop.

Švankmajer has on numerous occasions remarked that his work has been influenced by two broad artistic modes, Mannerism and Surrealism, which according to Arnold Hauser share a strong connection, making the distinction between these two influences

1 Karel Teige (1900-1951) was a major figure in the Czech avant-garde movement Devětsil; this Modernist arts and culture movement gave birth to the rise of Poetism and militated for the transformation of language into visual art. Teige and his group exploited the artistic potential of photography, film and new developments in book printing. Teige in particular experimented with photomontage representations of dreams, influenced by the psychoanalytical interpretations of Sigmund Freud and Otto Rank. 
in Švankmajer's films complicated and rather difficult (HAUSER 1986). However, Mannerism was a style of a particular cultural, political, social, economic and intellectual period, which was identified mainly post facto, unlike Surrealism, which is a self-conscious movement with official members, manifestos and dedicated publications. The basic feature that Surrealism shares with Mannerism is the dualism of fundamental outlook since in each school many concepts are fused with their opposites: rationalism with irrationalism, sensualism with spiritualism, tradition with innovation, conventionalism with revolt; the strongest link between the two idioms, therefore, is the tension between opposites that they express, which is channelled into creative activity.

Surrealism often harks back to occultist and Romantic cosmic theories in its proposal of new ways for seeing reality. Švankmajer, as a Surrealist, distrusts any revelation that lacks the sense of the enigma as a complementary aura of the hidden that awaits to be revealed. Švankmajer's deeply instinctive affinity with Surrealism is inflected by Czechoslovak culture and his work is placed in an established Czech tradition, that of the puppet and marionette and the cultural atmosphere of sixteenth-century Mannerism, most evident in Rudolfine Prague, the city of the Alchemists. André Breton considered Prague to be a city unique in its inspiration for Surrealism and, paraphrasing Apollinaire, called Prague 'the magical metropolis of old Europe'. Prague is a condensation of Mannerism and Surrealism, embodying in itself the extraordinary and Rudolf II, a new Hermes Trismegistos, as he was regarded by the initiated of that time. Rudolf made Prague the main court of the dynastic union and one of the most important centres of European culture; his patronage of the arts and sciences was wide in range, imaginative and often bizarre in its content. Rudolf's court was notably a centre for Alchemy and Magic in the sixteenth century, particularly focused on the Golden Lane (Zlatá ulička), which was the legendary street of the alchemists, in which Franz Kafka was later to live. Švankmajer has cited Prague as one of his most important influences (STAFFORD 2011), and his links with the ideas and imagery, rooted in the traditions of magic, alchemy and cabbalism, have perhaps derived from the City of Alchemy. Prague's strong alchemical and cabbalist historical background becomes an inspiration in Švankmajer's work along with Surrealism, one of the few movements of the twentieth century to embrace alchemical and cabbalistic notions.

Notwithstanding this, the cinema of Švankmajer seems extremely anti-occult, as it embraces brute reality and incorporates a rigorous materialism. Nevertheless, Švankmajer as a filmmaker ritually collects objects, sometimes arranging them in taxonomies, which he later subverts; he tests them in various combinations, with no limit to the ars combinandi of the Surrealist analogy; and eventually extracts out of their complex and accelerated fusions and confusions a superior quintessence, the analogical principle itself, the secret of Surrealist creativity, as a result of an experiment. Švankmajer creates a form of animation that is one of transformation, or transmutation, before the audience's eyes, from an object to its broken parts or substance, and vice versa; and in this aspect, his work is alchemical. 
Švankmajer has admitted that Mannerism has been an inspiration in his work and despite the filmmaker's attempts to expunge its influence, Mannerism keeps lingering on (KRÁL 1987). Some of Švankmajer's most characteristic early practices bear comparison with those of a Mannerist artist, deemed as the precursor of the Surrealists, whom the filmmaker acknowledges as an influence in his work (CONCANNON 2012). The Italian painter Giuseppe Arcimboldo (1527-1593) was active in Prague during the late sixteenth century and even though he was obliterated in the history of art until the twentieth century, he is now celebrated as an enigmatic painter of portraits, influencing and related to many aspects of Modern art, such as Dada, Surrealism and Pop Art. Arcimboldo, exploiting a Mannerist formula, the concetto style, created trick portraits, in which human faces, profiles mostly, are comprised of realistically represented objects and natural elements that turn into the fantastic form of real or abstract entities. These compositions, which suited the allegorical types of representation of that period, were not merely caprices of the artist's imagination, but, according to contemporaries, they were portraits actually resembling their living models, such as court figures, or the Emperor Rudolf II himself. The systematic aspect of these pictorial fabrications is reflected in their constitution in series, and the fact that they operate on at least three levels of signification, combining the literal with the allegorical and the symbolic. Arcimboldian practices (either assemblage or collage) can be traced in Švankmajer's puppet films: Jabberwocky or Straw Humbert's Clothes (1971), Punch and Judy (1966) and the feature film Faust (1994); they are more evidently present, however, in his animation films: Game with Stones (1965), Et Cetera (1966), Historia naturae (suita) (1967), and Dimensions of Dialogue (1982).

Arcimboldo's work is a striking precedent for Švankmajer's cinematic portrayal of his own daring puzzles and complex transformations, even though the latter's use of the Mannerist formula is different. Švankmajer as a filmmaker can represent the actual construction and deconstruction of an object and its composites in a film, a method connected with the notion of object-animation in the non-filmic sense, in this way, he can be seen to breathe new life to the real world of objects. Švankmajer grasps the core of the motivation behind Arcimboldo's artistic formations - a desire not to convince the spectator that a particular material object has disappeared, or transformed into something else, but rather an emphasis on its very precise material qualities as a result of its effective dislocation from a habitual environment and re-location into a new artistic context - he therefore seeks to animate the real, exerting an ascendency over the non human world. Such an approach 'animates' in the sense that it breathes life into what is dead, or has never been alive, the most primitive of all human fantasies.

Švankmajer is also interested in Arcimboldo as a figure within the bizarre court of Rudolf II and the film Historia naturae (suita) is specifically dedicated to the Bohemian ruler. Arcimboldo was employed as court portraitist and organiser of entertainments, as well as the curator of the Imperial Wunderkammer. These Renaissance 'Cabinets of Cu- 


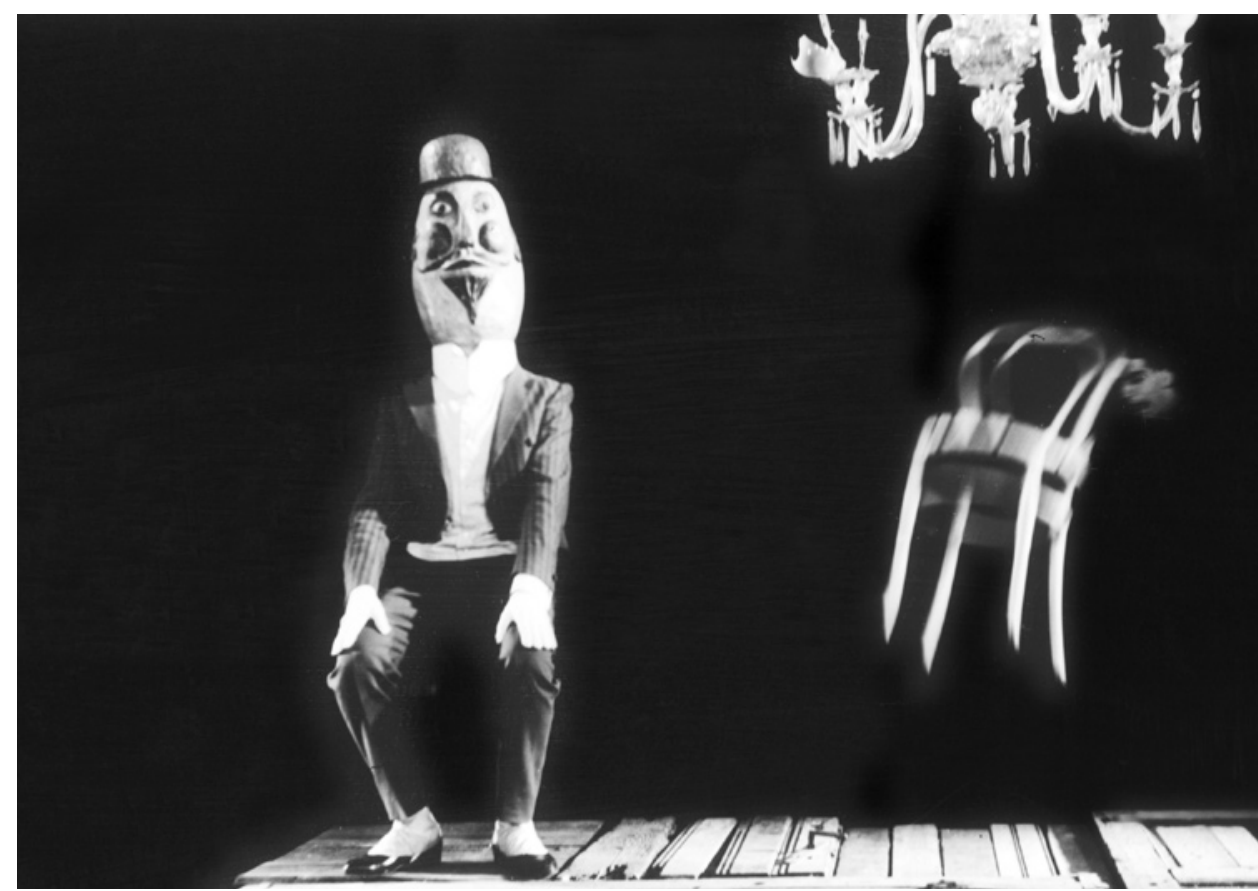

Fig. 1: The Last Trick of Mr Schwarzwald and Mr Edgar (Posledni trik pana Schwarcewalldea a pana Edgara)

(C) Krátký film, Prague, Dokumentární film, 1964. Duration 11’30”. Director Jan Švankmajer. Images( ${ }^{\circ}$ ATHANOR film production company, Ltd. Publicity stills reproduced with permission.

riosities' contained rare or spectacular material objects, which could also be conceived metaphorically as elements of fantasy, transformed from the real into the chimerical and vice versa, anticipating in many ways the Surrealist objects of later centuries. The owners of such cabinets tended to give pride of place to objects reflecting the human being's strife for mastery over the cosmos, the desire to collect material specimens, and the need to fix information through taxonomies and inventories. Such semiotic preoccupations find a parallel in the cinematic work of Švankmajer - who, as a master filmmaker, shares with his Mannerist forbears a collector's obsessions, a taste for anything old and bizarre and a passion for enigmas and alternatives in his practice of ars combinandi in order to transform the ordinary into the wonderful.

Mannerism finds its filmic equivalence in Švankmajer's work in the displays of sheer virtuosity in film making, in both his films' construction, or their forms and images; it is also present in the mixture of different visual styles in the film, the eclectic, disconcerting density of figures and objects within the film frame, the use of extreme camera movements and a reliance on unexpected or abnormal perspectives and angles. This is particularly true in the filming of puppets, marionettes, dolls and effigies; the portrayal of these objects is effected in images with distorted proportions and scale, achieving an 
atmosphere of discordance and a sense of playfulness, accompanied and heightened by swirling and at times highly strung music and exaggerated or mundane sound effects, resulting in an obscure and manic aesthetic composition.

Švankmajer's work after Soviet repression of the attempted Prague Spring reforms in 1968 is undoubtedly political; and Surrealism is an integral part of that political stance. Therefore the filmmaker's Mannerist influences and tendencies are often utilised for, or transformed into, political and Surrealist representations. Under the impact of politics, therefore, Mannerism and Surrealism in their common aspects became a unit within Švankmajer's artistic creation.

The wide variety of work that Surrealism embraces as a cultural movement, along with André Breton's own continuous revision of the movement's principles, makes the articulation of the movement's defining features extremely difficult (ALOQUIE 1965). Švankmajer as a practicing Surrealist artist, obviously shares concerns with Surrealism, however his own allegiance is more akin to the sarcasm of Benjamin Péret, rather than to Breton's lyrical Surrealism. Švankmajer's connection to Surrealism is apparent in his interest in the transformation of the real to the imaginary and vice versa, the animation of inanimate objects, and, contrariwise, the use of puppets, marionettes, dolls and effigies, the fragmentation of the body, collage, the tactility in objects, sadomasochistic violence (containing elements similar to Dalís paranoiac critical method), the obsessive exploration of childhood via memory, fantasy and dream, black sarcasm, the grotesque, the absurd, the concrete irrational, the uncanny, the outmoded and the marvellous.

In the course of his work, Švankmajer deals with a particular type of inanimate rendering of the animate: the manipulation of puppets, marionettes, dolls and other mechanically operated effigies. His use of these objects has its roots in the ancient art of puppetry, as well as the legend of the Golem. Švankmajer has remarked that he creates his 'Golems' to protect him from the pogroms of reality (HAMES 1995). The Golem is a figure of a legend from Prague with links to the Jewish Cabbala. It is a clay figure, which was given life, by writing on its forehead the word Emet (life). When only one letter, the $\mathrm{E}$ is stricken out, the word becomes Met (death), therefore, life and death depend upon one letter and the person who manipulates this fact is a kind of an alchemist, looking for the secrets of being and un-being.

Švankmajer is an alchemist animator, dealing with puppets and marionettes that best symbolise the manipulated character of man in the contemporary world; but his use of puppets and marionettes is always cognisant of their history and tradition - and to this extent they are less the embodiment of a symbolic attempt to portray modern alienation, and are rather a more creative pursuit aimed at developing and expressing the emotional connotations that such objects can carry. Nevertheless the surrealist 'chance meetings' of animated objects in Švankmajer's work and their irrational dialogue are more an expression of 'ideology', the rebellion against utilitarianism, than 'convulsive beauty'. 

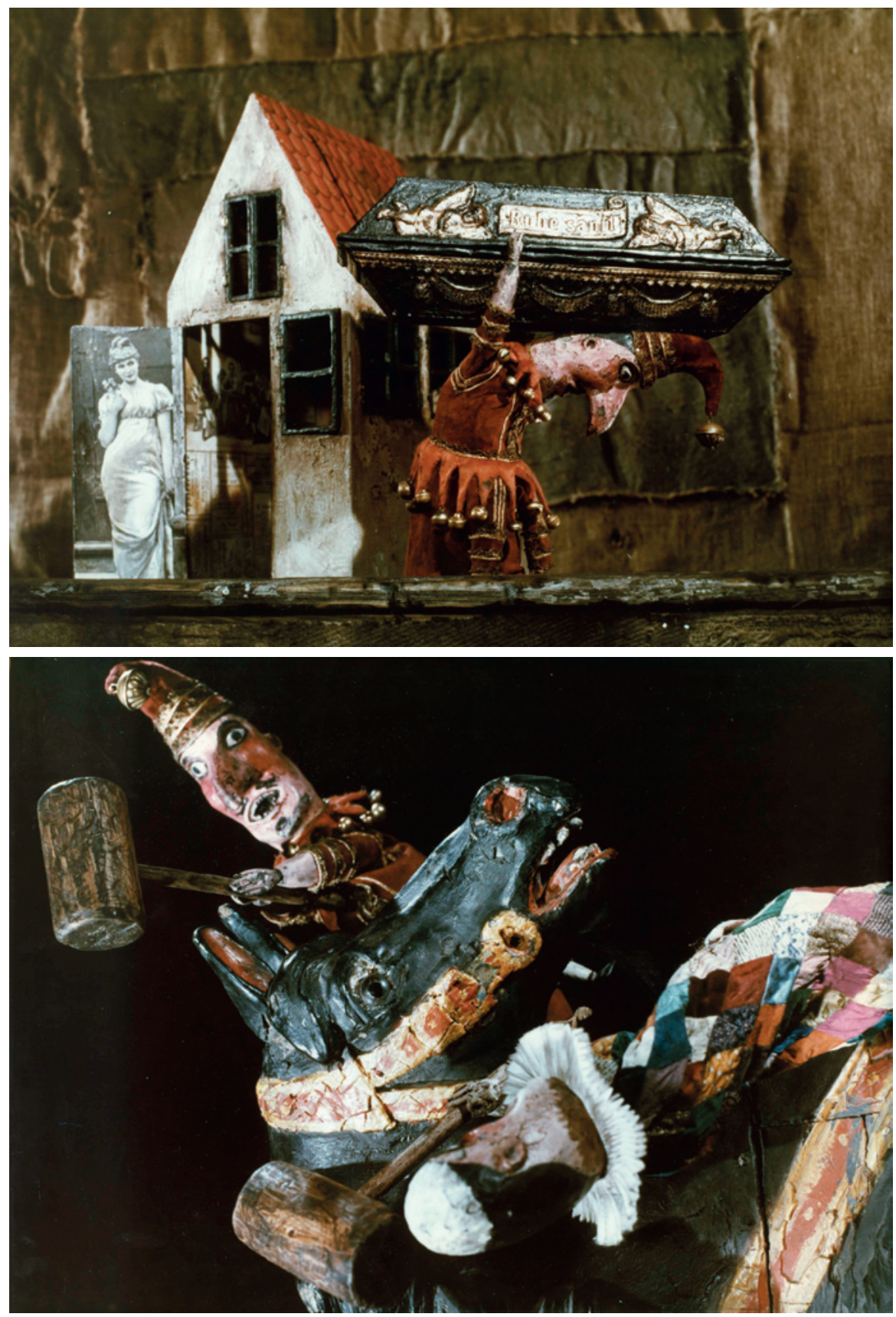

Fig. 2a+b: Punch and Judy, aka The Lych House or Coffin Factory (Rakvičkárna) (c) Loutkový film, Prague, 1966. Duration 10'. Director Jan Švankmajer. Images (c) ATHANOR film production company, Ltd. Publicity stills reproduced with permission. 

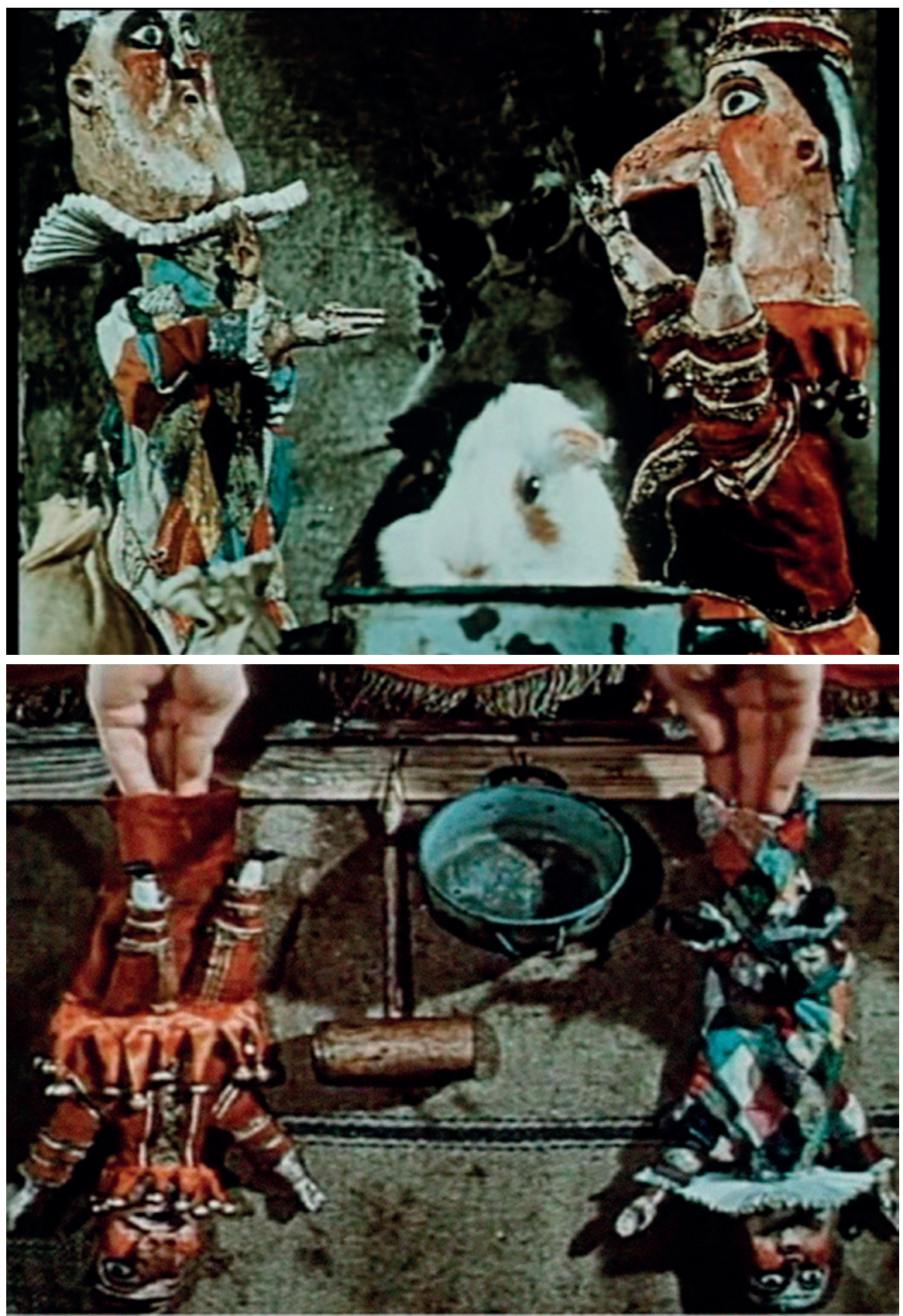

Fig. 3a+b: Punch and Judy, aka The Lych House or Coffin Factory (Rakvičkárna) (C) Loutkový film, Prague, 1966. Duration 10’. Director Jan Švankmajer. Images (c) ATHANOR film production company, Ltd. Publicity stills reproduced with permission. 
Marionette and puppet theatre have performed a unique historical role throughout the tormented history of Bohemia and later Czechoslovakia; at many points in history, this formed part of a need to protect Czech culture, and also constituted a form of protest and revolt against authority. With such a history, the domination of Czech animation by puppetry is also of political importance and Švankmajer's protest can easily be seen as part of this long tradition. Marionettes as an artistic form have strong historical and cultural dimensions, and when they become the dramatic cinematic subject, they introduce theatricality as a form of representation - a way of signifying human experience and the ways in which it can be artistically communicated that existed before and outside cinema, but is now captured in film. Švankmajer considers the old folk puppet theatre as unique (HAMES 1995) because, in its endeavours to meet the standards of great theatre as a form of art with the use of inferior and undermining technical means, an authentic stylisation emerges in its performances that is unique and comparable to the forms of stylisation that arise from paucity of theatrical means that characterise traditional oriental theatre (such as Japanese Kabuki, or Chinese opera). Švankmajer has admitted to a certain weakness towards the decayed genres of folk art, such as puppets and the scenery of folk puppeteers, because they enclose for him a special kind of magic.

Breton celebrated in his articulations of Surrealism two main examples of the inanimate and the animate: the mannequin of twentieth-century consumerism and the Romantic ruin. These he deployed either in juxtaposition or combination. The mannequin is a hybrid of the human and the non-human, an incorporation of capitalist commodity into the human form, and the Romantic ruin is a mix of the historical and the natural, a fusion of the historical edifice or artefact with wild nature, as Foster remarks (FOSTER 1993). They both are sources of enchantment and prime examples of the marvellous.

There is an everyday magic found in chance meetings and in decadent artefacts and products; this, combined with the fact that objects are both utilitarian products and magical tools in the hands of the creative artist, makes Švankmajer's use of them of particular note. Švankmajer generally uses the 'magic' of objects as a creative principle in his imaginative cinematic production, but particularly in the case of the puppet and the marionette. With this category of object, the filmmaker either employs antique looking marionettes (merging Breton's mannequin with the Romantic ruin), or he incorporates the romantic ruins of a literary past in his work (amongst them antique puppets, marionettes and dolls). These are for Švankmajer objects that have been abandoned, and are now ruinous and decaying; they must therefore be revived within a new cinematic reality, expressing an articulation of what Breton and Louis Aragon understood as the 'outmoded'. Švankmajer undertakes in his films this systematisation of reality through the perversity of imagination into a transformed world, in which 'decadent' objects, rejected and marginalised by contemporary civilisation can be recuperated and restored within a system in which they can have a new form of life, and leap into the marvellous. The animation of real objects is a leitmotif in Švankmajer's work and he claims that animation 
should exist 'to let objects speak by themselves' (EFFENBERGER 1987: 33). To do this, Švankmajer employs the apparent 'magic' of his cinematic art (in reality the slow process of stop-frame animation) to reveal a proposed secret life for objects by animating them, he is both a demiurge, creating a new cinematic world and breathing new life into its inhabitants and a sorcerer, anticipating and witnessing the results of his magic spells.

Švankmajer uses marionettes and puppets, as well as masks of antique appearance, which echo the long and rich Czech tradition of puppet theatre, particularly in his early films. As a cinematic subject they are more characteristic of the beginnings of Švankmajer's career, which was clearly influenced by his original profession as a puppeteer. Švankmajer uses this type of puppets, marionettes and masks in the films The Last Trick of Mr Schwarzwald and Mr Edgar, Punch and Judy and Don Juan and he returns again to the antique type later in Faust and Alice. However, in Alice and other films, such as Jabberwocky, the anthropomorphic role of stylised puppets, marionettes and masks in the tradition of folk puppetry is taken over by children's toys, particularly dolls.

In The Last Trick of Mr Schwarzwald and Mr Edgar, the first of Švankmajer's films as a director, a rivalry between two magicians who try to outdo each other by performing various stage tricks, is unfolded on stage for the pleasure of an unseen audience. The two magicians perform an elaborate, theatrical competition, in order to prove who can deliver the best magic trick; but, as the tension rises between the two magicians, the conventional competition becomes an absurd battle. Each magician is trying to outperform the other with increasingly irrational and outrageous tricks and props, carrying their battle to its extremes. For The Last Trick, the two magicians make themselves disappear, by tearing themselves to pieces.

The rivalry between the two magicians thus unfolds within the stylised framework of a mock theatrical performance and it is played out to a rhythm of action underlined by the use of certain cinematic techniques. Švankmajer's work has been greatly influenced by his theatrical background and his educated experiments within Czech puppet theatre. In The Last Trick the director pays his respects to Czech theatre, using techniques from two forms in particular: the Theatre of Masks and the Black Theatre. These references are made through the combination of living actors and puppet heads, through a living creature, a beetle, performing in the play alongside inanimate puppets, and through the disclosure of the reverse side of the theatre's wings.

Švankmajer's fascination with the corporeality of an artificial animated being thus develops around this strong sense of traditional Czech theatricality and in The Last Trick the director persistently blurs the states of being, the animate and inanimate, by using living actors disguised as puppets. The two actors, impersonating puppets as magicians, wear giant antique puppet masks on their heads, giving the impression to the audience that they are living marionettes without strings. These creatures refuse to exist in a defined state, and act as either animate or inanimate in the film; Švankmajer, as the 
director and metaphorical 'puppet master', manipulates them within the course of the story accordingly. The film begins in a unique way as Švankmajer shows the cinematic viewer the truth, which is not meant to be revealed, either to the theatrical audience or the cinematic viewer, as well as the reality hidden behind the theatrical scene and the anticipated show. During the opening sequence and the credits of the film the living actors are briefly exposed, according to Philip Strick 'as if in furtive apology' (STRICK 1986: 223) to the cinematic viewer. This revelation of the inner workings of The Last Trick to the cinematic viewer and the theatrical audience is further enhanced during the same opening sequence through exposure to the camera of various parts of the scenery and props that will be used in the film (which are glimpsed briefly along with the actors). Švankmajer provides the cinematic viewer with the extraordinary shot of one of the actors, impersonating the magicians, before wearing his puppet head on, sitting at the theatre's backstage. In this shot, the actor is used as a visual channel through which the opening credits are presented; one is placed on the wall behind his head and the other on the sole of his shoe. The inclusion of this shot is undoubtedly a bold directorial statement, nevertheless it is remarkably subtle in its delivery - which preludes the cinematic viewer's access to reality becoming fiction and vice versa and the inanimate anthropomorphic artefact becoming animate and contrariwise, which is witnessed also in Švankmajer's later works embracing the theatre and involving puppets (as in the short film Don Juan and the feature film Faust).

The cinematic viewer of the film, if not the theatrical audience in it, therefore knows from the start of the film that the 'puppets' performing, are actors wearing puppet masks; nevertheless, Švankmajer perverts the real image of the actor, which the cinematic viewer is allowed to witness at the start of the film and is not going to view again till the end, and effortlessly leads his audience(s), both cinematic and theatrical, not to evaluate and accept the real facts, but rather to become aware and understand the animation the director creates through the prism of the Surreal; this clever cinematic manipulation is thus presented as heightened realism within the mental framework of real live action. Accordingly, even though the cinematic viewer and the theatrical audience already know that the actors are disguised puppets, eventually they are never certain of what is hiding behind the mask.

In this double-sided way, Švankmajer manages skilfully to preserve the magic of the animated film within the revealed 'truth' of the tricks he uses as a filmmaker - and he does so in order to make the real become imaginary, and vice versa, in terms of the reality behind the show. The techniques of animation Švankmajer uses as a director are revealed to the cinematic viewer before the animation he creates in the film itself. Švankmajer's cinematic 'magic trick' as puppet master is one of subverted theatrical animation, he uses live actors in the guise of wooden stage puppets, confusing the viewer's senses with this blend of animation of the inanimate and its opposite; in doing so, he alters their perception of what is alive and real. 
The film impresses with its cinematic qualities and range of animation techniques, but it is clear that Švankmajer's unique style owes more to scenography, graphic art and cinema than the fine arts, and retains a theatrical point of view by preferring frontal long and medium perspective shots, characteristic in most of his films, and avoiding the diagonal shot/reverse shot. Švankmajer also uses techniques of fast camera movements and rapid editing, echoing the influence of Soviet cinema, as well as extreme close-ups, stressing the shapes and patterns of the objects portrayed (such as the antique wooden heads of the magicians and their tactile characteristics), in order to heighten the energy of the film and the power of the images, which flow within and between the frames and shots. Although Švankmajer is not primarily concerned with continuity in his style of editing, regarding form and context in most of his films, in The Last Trick of Mr Schwarzwald and Mr Edgar he uses the chandelier to guide the cinematic viewer and lodge the film in a coherent space. The chandelier appears in many shots and its exact position changes, either to the left or the right of the frame, indicating each magician's performance in a cinematic spatial grammar that also formalises the adversarial divide between the two performers. In the final shot of the handshake of the magicians' arms, the chandelier appears in the middle, stressing the symmetrical detente of their stalemated truce. In The Last Trick, by using stop-frame animation, Švankmajer achieves the impression of movement in filming the magicians during their performances, but also enhances certain of their uncanny elements, such as in the case of the frame-byframe composed shots of the eyes on the partial faces of the puppets in which they seem to move, but they are uncanny in their stillness. Similarly, by using the stop-motion animation technique of pixilation, in which the living actors are used as a frame by frame subject by the animator, Švankmajer gives the impression of movement in filming the bodies of the magicians, as they flit around the stage, and he transforms living actors into uncanny, living stop-motion puppets.

The use of these particularly cinematic techniques (which manipulate the progressive temporal experience of several moments of the filmmaking and film-watching process: the observation by audiences of film in real time, its shooting in non-sequential, manipulable time, and its editing to alter its representation of time), which are very characteristic of Švankmajer's work, also results in a fragmentary and disjointed style of filming, which could be interpreted as a Mannerist influence. By contrast, the appearance of images of nineteenth-century idealised women and old printed material, such as music sheets, in the film could be identified as a more Surrealist touch.

Švankmajer also uses the film's sound in a fascinating way, mixing the song of an old phonograph with diegetic sounds and other sound effects, such as the audience's clapping or sound effects, suiting a theatrical performance.

Švankmajer's ability to manipulate and transform reality through the cinematic medium in The Last Trick and the mix of colliding images of puppets and artefacts in juxtaposition, appearing to float and fly unaided through space is reminiscent of another cine 
magician's work, Georges Méliès's joyous cinematic spectacles. Furthermore, in The Last Trick of Mr Schwarzwald and Mr Edgar, Švankmajer applies one of the principles of silent comedy, rooted in the art of mime as a theatrical medium, or performance art: that of 'an eye for an eye', but ingeniously the object of destruction at the black humorous end is not the various artefacts, but the two magicians, the animated puppets. The black backdrop, against which the puppet actors perform and that is used to frame the theatre stage, allows a type of performance, resembling Bunraku puppet theatre. However, Švankmajer invests his puppets, as well as other artefacts and objects in his films, with a powerful and overwhelming essence of materiality (they are most definitely 'things'), underlined with extreme close-ups, cinematic shots that serve not to reflect mainly expression and reveal intent or emotion in the puppet performance (as the case is in a Bunraku performance), but rather to draw attention to the physical textures of the puppets' appearance. Furthermore, in The Last Trick, as the puppet magicians become endlessly mutable bodies, transforming, generating body parts and objects, and multiplying to excess, eventually reducing themselves to destruction, the artifice is never seamlessly suggestive, but always signposted and enhanced by the stolid expressions on the masked faces of the puppet actors and their gestures and performance, conveying a sense both of procedure and routine.

The major themes of The Last Trick are in this way clearly communicated through the puppets' performance: alienation expressed by the antique puppets, as mechanical systems that get disordered with the interference of an external factor, a beetle, shown besieging the mechanism of the animated puppet, and infantile cruelty that leads to the mutual destruction of the two protagonists.

The concentration of allegory, metaphor and allusion typical in Švankmajer's work and the uncanny puppet-hood of the characters urge various readings. Švankmajer involves repetitive, mechanical situations throughout his work, in both his short and his feature films, and, in the case of The Last Trick these mechanical situations continue until the mechanism breaks down. The situation is characteristically described by Dan North as being: 'as if the film itself is wearing out its own structural circuit' (NORTH 2009). The puppets, which are basically humans, but they are presented as artificial agents, brainless machines, go through a communication breakdown, during which their hands are the drivers of the interplay, the indexes of behaviour and denotation, referent or idea, communicated by means of their gestural language, while their heads are empty of brains and agency, serving as containers of objects, mere receptacles for the apparatus of the magical spectacle, the ultimate creative act. Throughout The Last Trick, a beetle is glimpsed, crawling on the magicians' wooden faces and inside their skulls and internal mechanism, oblivious to the increasingly violent contest between the two magicians, until eventually it is presented dead in the final shot of the film. This visual depiction can be interpreted as a creative insight, resembling a nagging idea, which apparently becomes a casualty of the destructive showdown. Insects could be characterised as the 
automata of nature; they are mechanical little creatures with a gait like clockwork and with an often-rigid body structure; nevertheless, in The Last Trick, the beetle is the most vivid creature on display, compared to the animated puppet conjurors on show in this film. Paul Wells, commenting on the film, remarks:

Švankmajer uses the ritual of performance to suggest a model of difference only to imply that humankind will always fall prey to its own inability to properly reconcile the repeated failings and flaws of its evolutionary sensibility. The two magicians in The Last Trick are metaphors for Švankmajer's social vision as it is played out through the contradiction inherent in the body as it is simultaneously liberated though art but mechanised by socio-cultural practice. Švankmajer's quasi-surrealist approach represents the magician as a mechanism which possesses the inherent possibility of failing. (WELLS 1999: 187)

In The Last Trick, the living insect is essentially the catalyst by which the interface between human and machine fails, whereas its dead image in the final shot of the film as a 'Kafkaesque harbinger of supernatural change' is underlining this failure of the process to join the human to a machine, an automaton, making the cinematic viewer aware of the unsuitability of a mechanism to accommodate the widths and limits of human expression. In The Last Trick, Švankmajer uses animation to articulate his social, cultural and political theses; these concern the position of human subjects in society; Švankmajer wishes the cinematic viewer to dislocate themselves from the events on screen and substantially reconfigure their own place, as an individual and part of an audience outside from and within the film. Furthermore, the film is a vivid illustration of the specific ways in which artefacts, and particularly puppets/automata, function in Švankmajer's work operating a duality as subjects and objects that calls into question most modern humans' conceptions of their own levels of agency.

Puppets, as inanimate creatures, have often been used in plays to replace human performers in order to stand in for a prevalent ideology, or embody a particular theme, concept or emotion because the author deems that a real person might pollute the play's messages with individuality and specificity. In the story of The Last Trick, the element of the duelling magicians, who are human puppets without strings, escalating their magic spectacles in a competition with a destructive outcome, could therefore be seen as a reflection of a real life story, that of artistic creation, corrupted by political or commercial pressures; in this dystopian vision, the winner is the artist who would compromise his artistic expression the most, sacrificing both body and soul and becoming a puppet for the state's and the authorities approval as well as a target for the brainwashed audience's applause and delectation. In such a reading, the dead beetle might therefore be ultimately reflecting the consequences of artistic conflict, and representing even in resistance to social, political and cultural conformity, the inevitable collapse and death of creative expression - a sentiment 


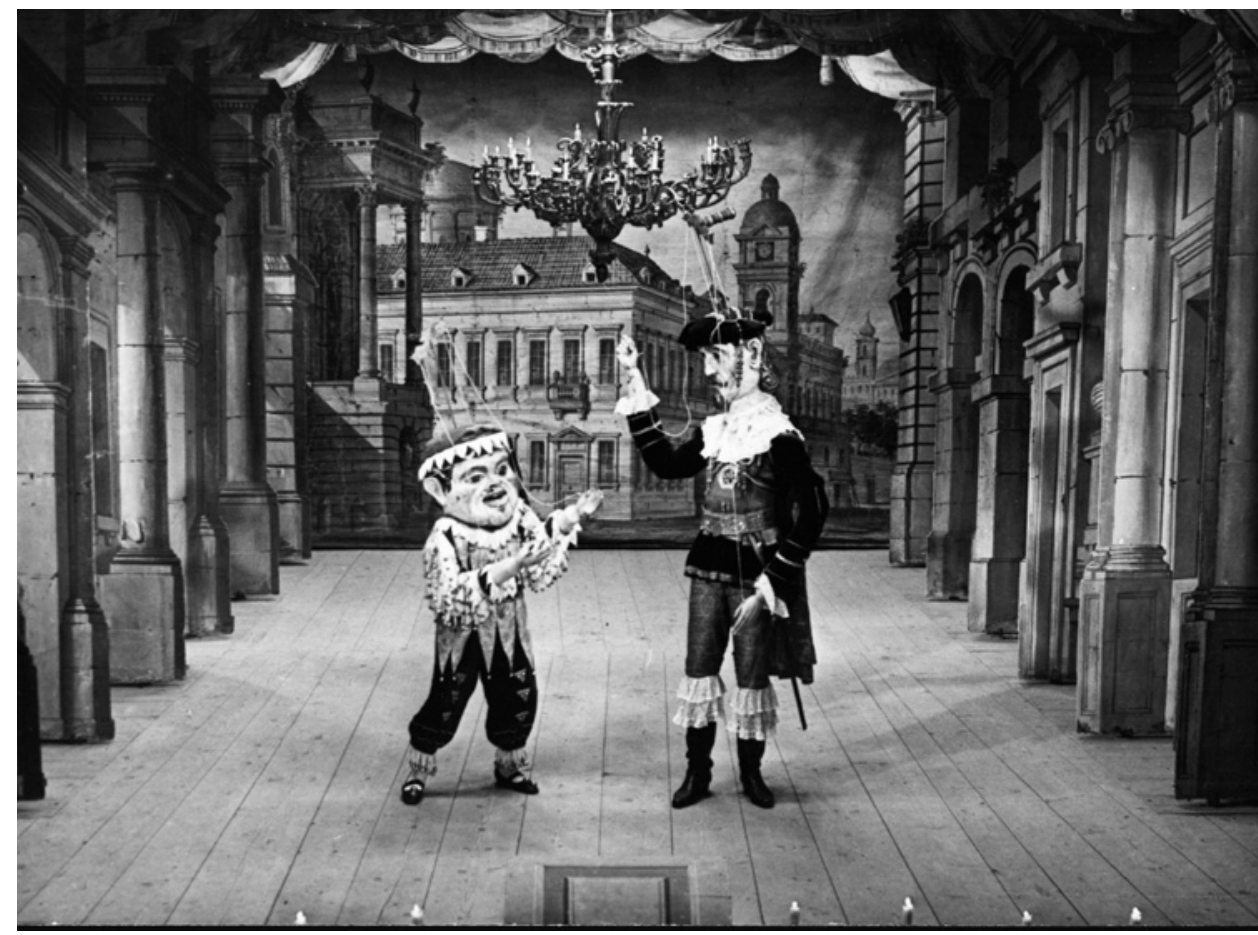

Fig. 4: Don Juan (Don Šajn). Krátký film, Prague, Dokumentární film, 1970. Duration 31’. Director Jan Švankmajer. Images (c) ATHANOR film production company, Ltd., reproduced with permission.

familiar to Švankmajer's own artistic experience and social, political and cultural conflict with the governments under which he has tried creatively to express himself as an artist. The violent disembodiment and destruction of the two magicians, the human puppets, whose artificial character frustrates any notion of verisimilitude in reading the violence, might thus be a dramatic illustration of the fact that the most ferociously fought battles are basically those between competing ideologies; their attendants, internecine struggles, signifying the impossibility of compromise.

The elements of combative communication and variegated violence appearing in The Last Trick recur most forcibly in Dimensions of Dialogue in which the filmmaker depicts a series of three physical destructions and communication breakdowns. In another one of his puppet films, Punch and Judy, Švankmajer cinematically plays with the element of primitive violence, using similar motifs as in The Last Trick and explores the notion of a living organism, human or other, versus automata and puppets. In Punch and Judy Švankmajer includes an animal, which can be compared to the beetle in The Last Trick, that also plays a central role in the film.

Punch and Judy or in its more literal translation The Coffin Factory or The Lych House, is Švankmajer's third film effort and a triumph of Surrealist satire. Švankmajer takes an old 


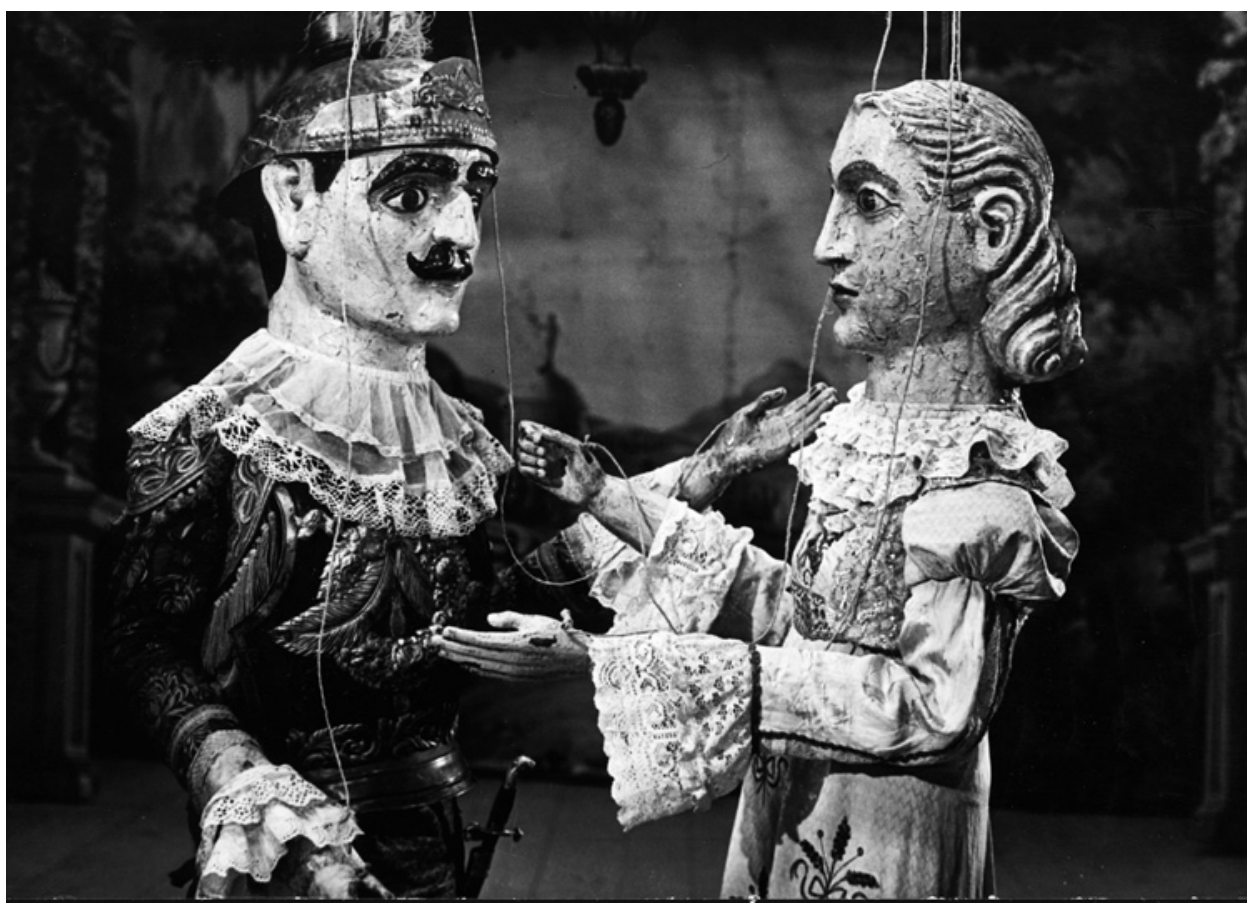

Fig. 5: Don Juan (Don Šajn). Krátký film, Prague, Dokumentární film, 1970. Duration 31’. Director Jan Švankmajer. Images (c) ATHANOR film production company, Ltd., reproduced with permission.

traditional puppet story, which still survives and is performed in puppet theatres, and transfers it in film. The Punch and Judy show is one of the most enduring cultural archetypes in the Western world, and is particularly popular in Britain; its story is characterised by both depth in meaning and vitality in performance. Ultimately, Punch remains a comical cultural symbol, used to examine personal faults of character and behaviour, such as vulgarity, cruelty, greed and violence, which are held up for ridicule before the audience.

Švankmajer's cinematic interpretation is a densely allusive and sinister exploration of the traditional puppet show, a darkly hilarious and frenetically charged piece of mimed puppet slapstick theatre. The storyline of the film is primitive and its plot concerns the duel between the famed glove puppet Punch and the lesser-known glove puppet Joey, who tie themselves up in a petty argument over the possession of a guinea pig. In the film, Mr Punch is caring for his guinea pig, feeding and petting the animal and his neighbour Joey witnesses the scene. Joey envies Punch for his possession of the guinea pig and tries to buy the animal from Punch, who is unwilling to sell the guinea pig to his neighbour. Joey makes several attempts to bargain with Punch for the ownership of the guinea pig, nevertheless Punch refuses every cash offer. Joey and Punch initially make 
rational attempts to strike a deal, however, the action quickly descends into violence after the transaction fails, as Joey sets on a selling price, regardless to Punch's disagreement and Punch decides to kill his neighbour and take the money anyway. The two puppets settle their dispute in a battle, each taking turns to kill and stuff the other into a coffin in an anarchic fight, which both characters survive after being incarcerated. It all ends with both Punch and Joey dead and boxed in the coffin, as the two puppets eventually kill each other in a scene reminiscent of the mutual destruction of the two magicians in The Last Trick. Only the guinea pig survives, which throughout the film nonchalantly chews its feed, munching at a tub of grains, and the film ends with the animal leaving the scene, ambling off stage through a hole in the scenery.

Švankmajer here embraces more fully the theatrical space of conventional puppet plays and announces the theatricality of such spaces in the prologue of the film, in which he deploys a clockwork orchestra of automata, mechanical monkeys playing musical organs, and introduces the audience to the world of theatre by presenting the accoutrements of a theatrical performance: the garishly painted theatre sets, the scenery and the stage within an entertainment fair atmosphere. The ensemble is underlined with the appearance of a carousel and the accompaniment of looped circus music. Punch and Judy is filmed, as Michael O' Pray remarks (O'PRAY 1988: 378), in what Effenberger has described as Švankmajer's 'fantastic theatrical review' or 'poetic music-hall show' style. This introduction to the theatricality of the film is further enhanced immediately after the credit sequence, at which moment the puppet master's hands are shown being inserted into the glove puppets, which are also shown at the end of the film when they disappear below the theatre stage. A similar reflexivity within the narrative of the film between theatrical reality and a wider reality beyond the theatre stage (that which exists backstage in the theatre, in the auditorium or even in the real world outside) is also experienced by the spectator in another two films: Don Juan and Faust; nevertheless, in Punch and Judy, Švankmajer is not significantly playing with different kinds or aspects of reality, because the spectator only witnesses the entrance and exit of the puppet master's human hands in what has been constituted as a theatrical space, and the existence of a living animal, the guinea pig, on the theatrical stage as well as the animal's exit from its premises. This is different to Don Juan and Faust, in which the interaction of the protagonists (both puppets and humans) with different realities and how these relate to the experience of the spectator are more complicated and obscure (i.e. the borders amongst those realities become less distinct, creating a more magical whole). As Dan North remarks on Švankmajer's work:

At their best his short films are as tightly structured as incantations, delivering a sequence of actions and a barrage of images that somehow add up to a perfectly arranged whole. That's not to say that it's easy or even possible to draw conclusions about what it means, what the conjuration of that incantation might be, and the lack of easy explanation for all of its imagery is unsettling. (NORTH 2009) 
Similarly to The Last Trick, Punch and Judy is built around the topic of a terminal battle between two puppets, leading to their mutual- and auto- destruction; the allegorical substance and symbolism of the film are thus more dense than its subject matter and setting suggest at first sight, because puppets invite to a certain extent allegorical interpretations. Even though the original historical use of puppets was to substitute for humans in performances, puppets have never been able to take on the character of simple verisimilitude. As performers they have always had an ambiguous and ambivalent identity that presents simultaneously a series of binary opposites: they are lifeless, inert artefacts and animated creatures; they assimilate a complex representational history and lack individuality; they accordingly unsettle the usually dichotomous line between life and death with their uncanny qualities and raise questions in relation to human identity and nature that extend beyond every play in which they are called upon to perform and any historical timescale. Švankmajer has pointed out in an interview: 'I believe that puppets best symbolise the character of man in a contemporary, manipulated world' a statement that underlines the symbolic significance that puppets hold for him in his work (HAMES 1995: 107). This contention, that puppets represent the social manipulations to which all people are subject, suffuses most of his films, portraying in malevolent human-animated environments artefacts and objects, puppets and automata. Thus Švankmajer's inanimate objects, given life and agency through animation, reflect a coherent worldview in which the human subject is pray to symbolically loaded devices (such as the mechanisms of state power, communist or capitalist), and the alienating impersonal nature of a consumerist social environment. By contrast, the living animal serves as a stark reminder of the glove puppets' inanimate state of existence in the world of anthropomorphic animation and the individual's artificial and self-destructive existence in a manipulated world. Punch and Judy symbolically mocks humanity, the state, and the mechanised human condition, and it brings this into play set against the individual's primeval desire for conflict - which seems always to be escalating and never ending, and results in humankind's own mutual and self-assured destruction. Such a bleak view can be seen to epitomise a personal and universal tendency towards a kind of social entropy. Notwithstanding this human destiny conveyed by puppets, nature, signified by the living animal, proceeds indifferent to human struggles - a fact that can be said to highlight the insignificance and pettiness of the human condition. Nature optimistically escapes disaster and goes on without humanity. The living creature in Švankmajer's films acts out, according to Michael O’ Pray:

both untrammelled desire, unmediated by conscience, morality or convention and almost paradoxically, its opposite, order and innocence, which can never partake in the aggression of the 'constructed creatures' (marionette-humans) whose world they cannot share. (O'PRAY 1988: 378) 

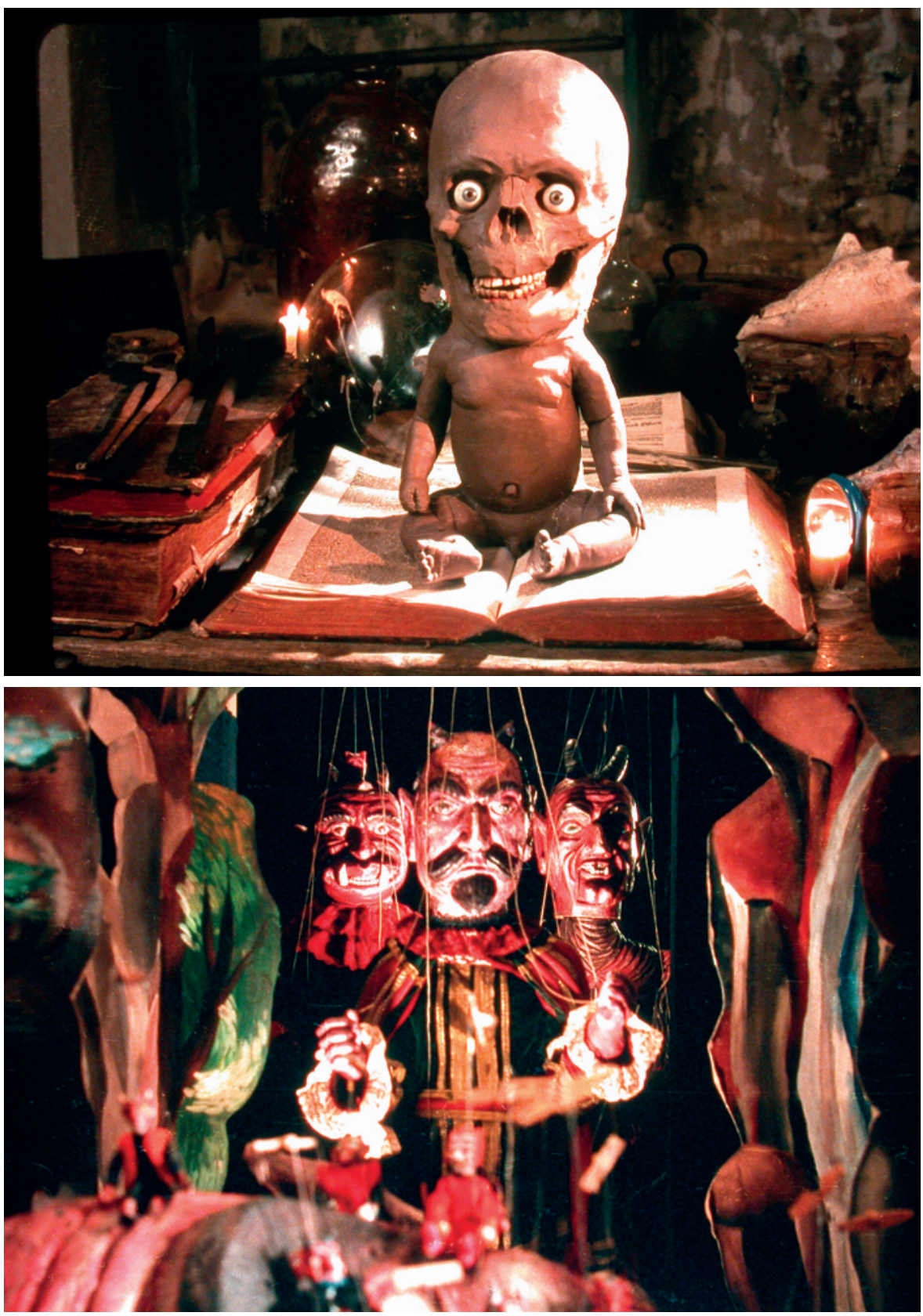

Fig. 6a+b: Faust (Lekce Faust). ATHANOR, Heart of Europe (Prague), Lumen Films, BBC Bristol, Koninck Film and Pandora Films (Frankfurt), 1994. Duration 92'. Director Jan Švankmajer. Script Jan Švankmajer, from the Faust plays by Goethe, Christian Dietrich Grabbe, Christopher Marlowe and Czech folk puppeteers. Images ๑ATHANOR film production company, Ltd., reproduced with permission. 


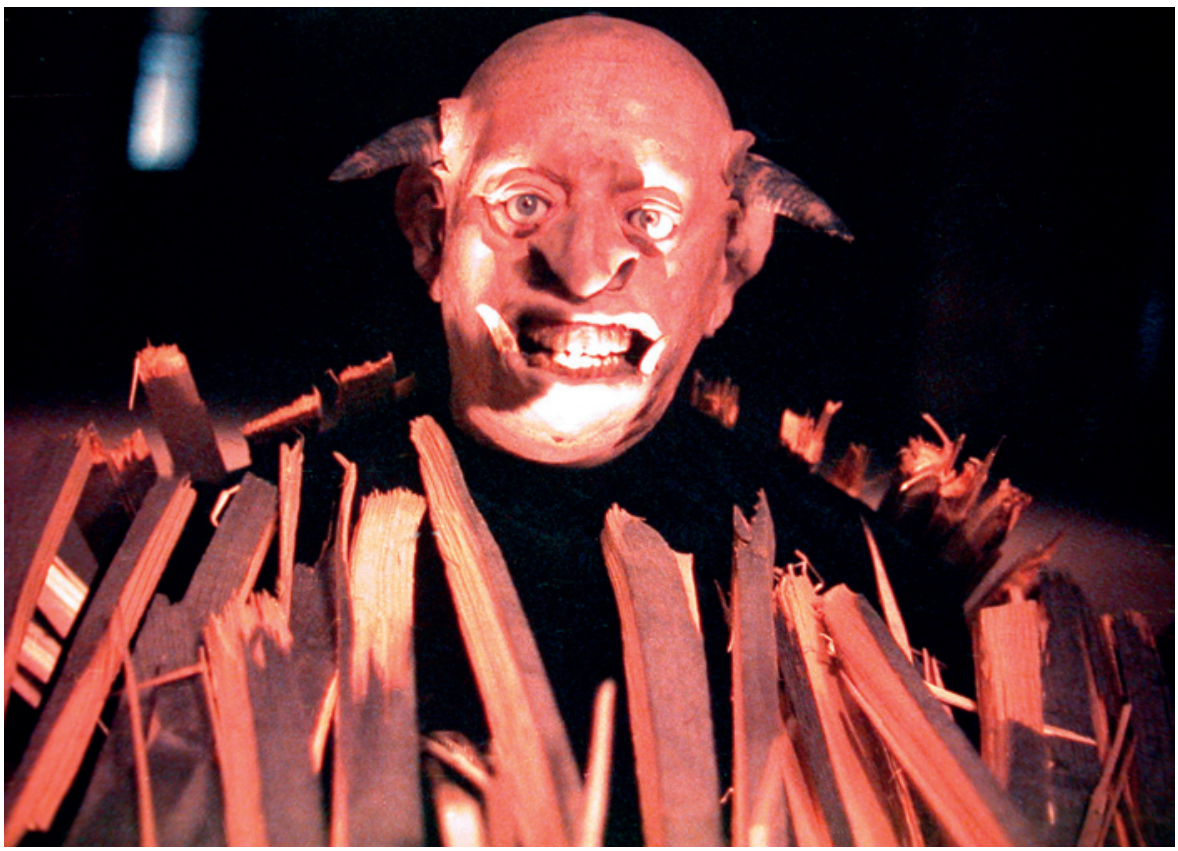

Fig. 7: Faust (Lekce Faust). ATHANOR, Heart of Europe (Prague), Lumen Films, BBC Bristol, Koninck Film and Pandora Films (Frankfurt), 1994. Duration 92'. Director Jan Švankmajer. Script Jan Švankmajer, from the Faust plays by Goethe, Christian Dietrich Grabbe, Christopher Marlowe and Czech folk puppeteers. Images (C)ATHANOR film production company, Ltd., reproduced with permission.

The fact also that the living animal takes on gigantic proportions next to a couple of artificial miniature glove puppets makes their struggle even more self absorbed, doomed and insignificant. As O’ Pray remarks:

There is a textural contrast here between the surfaces of man-made objects and the animal presence, but more importantly for Švankmajer[,] animals suggest the idea of the innocent cause [-] they are perhaps a surreal device for negating psychological motivation. They also express a supreme indifference to the fate of mankind and thus they act as silent reminders of a wider scenario, one that stresses the destructiveness of Švankmajer's puppets. (O’PRAY 1988: 378)

Švankmajer's surreal imagery thus re-purposes the traditional puppet play of Punch and Judy as a conduit for universal ideas and symbols and uses the self-destructive violence in the generically and dramaturgically pre-determined life of a particular puppet (Mr Punch) the equally inevitable and aggressive self-destruction of the entire human genus. Following the opening sequence of the film, which is filled with clockwork automata, the spectator witnesses the lifeless and limp bodies of the two puppets, Punch 
and Joey, being filled by the eager hands of the puppet master, filmed in stop-motion technique; their staccato clipped movement transforms the artificial creatures into convulsing cadavers before they have ever really 'lived'. Despite the fact that the animating hands of the puppet master are clearly visible to the spectator from the beginning of the puppets' performance, and given the simplicity of the illusion (which is created by the inanimate puppets acting as living creatures), while they become the extension of the puppet master's hands, Švankmajer's imagery is suggestive of man's own attempt at divine creation (or perhaps his wilful negation of the divine), as the director uses the puppets to explore the blasphemous image of an artefact, given an unnerving life, while the audience witnesses life seeping into the puppets' bodies and Punch and Joey taking on an uncanny life of their own. In an ironic contrast to the fates of the characters that these puppets are required to play, the real, material puppets of this film have no actual 'life' and therefore none of the fragility of humanity. Their real existence is not threatened by violence (at least not as much as a human's life is), but instead it is bolstered by violence; ferocity is the robustness, bursting with liveliness, of the puppets - and it is this quality that lends the film its most intriguing aspects. In traditional performances of Punch and Judy, the focus of the play is often on routine, which climaxes in a slapstick act, riding on a wave of laughter from the audience. Starting from this point, Švankmajer's interpretation of the traditional play uses violence to provide a strong 'punch' line (pun intended); however, as time passes, the violence escalates, escapes the typical antics of the stock characters and delivers a harsh commentary on the destructive essence of life itself. Švankmajer makes this statement, creating with his cinematic means a dizzying circle of violence, death and resurrection, which culminates in Surreal images of nails hammered into the puppet characters' faces and their heads splitting; scenes are accompanied by rhythmic sequences of images taken from newsprint, reference books and encyclopaedias and surrounded by clockwork automata and mechanical contraptions, setting the tone of the action in a world of man-made media. The two puppets, personifications of self-destructive evil, are gleefully engaged in a dance of death, stalking each other with vicious intent and letting their violence explode on stage, submitting to their predetermined fates, while the audience experiences this unyielding magic circle. The one puppet beats the other to death and then entombs the deceased, only to find out a moment later that the dead has risen from its grave in order to murder its murderer. This process repeats over and over again in a ritualised manner, and the film becomes a legible bitter satire of the cyclical nature of human conflict and self-destruction, which seems even more meaningless and pointless precisely because it is staged by puppets, artificial creatures caught in between an inability to live and an inability to die.

Nevertheless, once the puppets are beaten, crushed, nailed, becoming otherwise dead, or un-dead on stage over and over again, the puppeteer's hands reappear, recalling to the audience the fact that this play is, after all, the work of a single set of hands, the artist's (the State's? God's?) - a choice that remains untaken for the audience and is only 
ever suggested throughout the film - maximising the effect of the puppet drama, which becomes in all of its artificial and organic detail, as comforting to the audience, as the eventually ironic inscription on the coffin of the puppets, which reads Ruhe sanft, which translated from the German means 'Rest in Peace', or the bitter actual title of the film The Coffin Factory.

A film made under the influence of Švankmajer's theatrical experience and practice with intermedial performance at the Laterna magika theatre in Prague at the time, Punch and Judy encompasses and introduces thematic elements and visual ideas and motifs that are to be developed further and encountered again in later films. Further examples of this fascination are: the infernal machinery appearing in the opening sequences, introducing the credits, in Don Juan and The Pit, the Pendulum and Hope; the collage of nineteenth-century black-and-white photographs and newsprints, which has a strong use and presence in Jabberwocky; the holes that appear in the floor of the stage, in order to be penetrated by the fleshly hands of the puppet master are seen again in Alice (in which the house floor is perforated by living socks, behaving like worms); and the self-unscrewing screw in the coffin of the puppets, which turns up again in A Quiet Week in the House.

Švankmajer also uses techniques from the Theatre of Masks in Punch and Judy; in a tactic typical also to his other puppet films, he reveals the hands of the puppeteer putting on the puppet gloves to animate the puppets, whereas when they die at the end, the hands retreat under the stage again and back out of the frame. He also films another living creature, the guinea pig, performing along with the puppets, manifesting the uncanniness of the puppet and underlining its unreality by juxtaposing and contrasting it with a real animal in a kind of Brechtian trick. This coexistence of the puppets and the animal on the theatre's stage and also the living human puppet master, whose fleshly hands are slipping in and out of the artificial puppets, generates a bizarre tension and friction between the inorganic constructs and the organic elements featured in the film. It is in such juxtapositions that Švankmajer's ideological work is done.

Švankmajer underlines the cinematic confrontation of reality and fiction with the use of these techniques in Punch and Judy and emphasises the interpenetration of the worlds of real life and fantasy as well as their continuity. Interplay between several layers of reality takes place in this film, as the puppets interact within the limits of their collaged theatrical world, the guinea pig exists and wanders through this theatrical world (eventually exiting its limits as it wanders into the backstage of the theatre independently), the puppet master appears to be present in both the theatrical world and the world beyond it, seen momentarily as the animator of the puppets, controlling them from beneath the surface of the theatrical stage, but otherwise unseen and of course a representative of Švankmajer himself, the invisible puppet master, overseeing and directing it all, animate and inanimate.

The marionettes, performing in Punch and Judy, are meticulous copies of the seventeenth-century originals and combine Breton's two examples of the marvellous: the mannequin and the Romantic ruin. The puppets, worn away in their appearance, resem- 
bling ruins, which evoke the ravages of time, are magically restored in Švankmajer's cinematic world, getting a new life. Švankmajer thereby evokes the magically old in Punch and Judy by means of the authentic reproduction of the marionettes; this is added to through the use of props on the set of the film, such as old newspaper fragments, prints and photographs, celebrating the uselessness of an old object.

Švankmajer's predilection for tactility is thus in subtle ways linked to the ruinous, such as the decaying appearance of the marionettes (the irony is that tactile objects invite the touch, and yet it is the very touch-ability that constitutes their appeal that also destroys them, slowly, over time); but such materiality is also connected with the nature of other materials in the film, such as the rough fabrics, the grainy newspaper fragments and prints, the worn photos and the coarse coat of the guinea pig. From the opening sequence Švankmajer pushes texture to the foreground as the audience's tactile experience culminates in close up shots and partial shots, focusing on the organic and inorganic material employed in the film. The images of the decaying monkey automata constituting the musical band, the metallic clockwork contraptions covered with rust and paint chips, and the flaked carousel horses assault the spectator in shots with rapid editing, creating a sense of disorientation and daze to the audience and when, surprisingly, the dead eye of an animal slips in the sequence of the horses' artificial painted eyes, the morbidity and creepiness of the images heightens, as organic dead and inorganic matter are animated in an uncannily interlinked way. The living guinea pig makes its appearance on stage precisely at the point in which the audience are poised to watch a performance of artificial puppets, with the rise of the curtain on the proscenium arch. Instead, spectators view an extreme close up shot of the guinea pig's face and rapidly breathing nostrils, and, later on, its fur, eyes, teeth, and moving tongue. True to Švankmajer's delight in the detailed close ups of organic and inorganic matter is the disquieting and most striking image of the film, that of the puppet's stiff, worn and chipped hands caressing the warm, living body of the guinea pig and inspecting its orifices. The two artificial puppets, each one of them a masterpiece of craftsmanship and textural complexity, are thus set in a typically jarring and unnerving contrast - not only with the living animal, but also with the fleshly hands of the puppet master (which they briefly appear at the beginning and the end of the film). There is also a structural and textural juxtaposition between the three dimensional wooden puppets and automata and the two-dimensional metallic mechanical contraptions. Punch and Judy are puppets purposely aged, fashioned in an antique manner of the seventeenth century, Punch's face is reminiscent of a painted half moonscape, designed to appear cracked and dented, likewise Joey's form has flaws, scratches and crevices. Punch wears a detailed red costume with a matching hat decorated with a little metallic bell, which accompanies every one of his movements with its sound, whereas Joey is dressed in an extraordinarily colourful patchwork Harlequin gown. The textural nature of the film is striking, as it also focuses on the aged and tactile surfaces of objects constituting the scenery of the theatrical stage, heightening the 
sense of their materiality (their 'thing'-ness). The audience observes in close-up shots the ripped patchwork of burlap gunnysack that makes up the backdrops of the stage. The house belonging to Joey is wallpapered with old clippings from books and newspapers. The coffin, used by the puppets to bury each other in, is papered in a puppet-sized print of a skeleton and is then hammered, nailed and dripped upon by candles. Finally, in the frenetic battle between the two puppets, which kills them both, they drill holes with their bodies in the wooden floor during their chase on stage and they puncture the colourful paintings, which frame the scene.

Švankmajer uses his characteristic camera work and editing in Punch and Judy, accompanied by a soundtrack that mixes a musical chorus with diegetic sounds and sound effects; the ensemble creates a notion of cinematic space and time - and Švankmajer juxtaposes it with and simultaneously undermines it by an entirely different sense of theatrical space and time. A film-to-stage illusion is therefore made by usurping theatrical subject matter.

The focus on the features of the performance that is about to start with close ups shots of the mechanical orchestra, the clockwork contraptions, the painted scenery and the carousel, while the camera matches the images with a frenetic quasi automatic motion, gives the impression that the theatre is running itself with a life of its own. This illusion is shattered momentarily when the spectator witnesses the puppet master's hands wearing the glove puppets in slow motion - an action mirrored again at the end of the play filmed this time in stop motion technique, when the hands retreat back out of the frame and under the stage again.

Švankmajer sets up the expectations of the audience for a stately, mannered piece of theatrical art which maintains its distance from the cinematic action, framing the film explicitly as a theatre, with a proscenium arch and a stage; however he does not shoot the film like a theatrical tableau. Instead, the first shot after the curtain of the theatrical stage is abruptly pulled up is such an extreme close up of the guinea pig's face, that its long, brushlike fur seems to be rubbing against the camera's lens and its beady eyes and buck teeth are blurred and out of focus. In this way, Švankmajer deliberately disrupts the theatrical presentation of the film and he proceeds to further break down the film with a psychotic pace of the editing that is in accordance with the play's development and the actions of the puppets. Often the distinguishing lines between the separate shots are blurred, the images flicker by quickly, creating rhythmic flurries of movement, which culminate in animated sequences, not designed to be experienced by the audience as frames in isolation and individuated shots, but rather as a continuous flow of animated images. The extended fight between Punch and Joey is hysterical, seemingly chaotic and yet actually controlled by a very tight structure, as Švankmajer gives his characters close up shots, two shots and eye line matches all cut together in a dynamic editing that implies the agency and subjectivity of the two puppets. Furthermore, Švankmajer plays around with the score of the film, synchronising the puppet duo's wooden mallet hits with drum kicks and orchestral blasts, 
which give a syncopated quality to the rhythm of the film, as the coordinated sounds provide the rhythmic propulsion and set the pace of the editing.

As I have argued above that puppets symbolically represent humanity's limitations and excesses and stand in for the human kind in their performances; they here become more than vessels of satire and self ridicule to their audience. In Punch and Judy, Švankmajer's puppets, with their rigid unnaturalness and obsessive tactility, contain the potential to raise empathy and sympathy in the spectator with their actions, making the film into a Surreal evocation of the vacuity and artificiality of all human interaction. All of this is heightened by the fact that Švankmajer does not aim or suggest the total vivification of his animated characters, rather he ensures that they are meant to remain palpably rigid and lifeless, seeming uncannily to move, act and destroy themselves before the audience's eyes. Nevertheless, as the early Modernists with whom I began this essay knew, every truly creative act is an act of violence, because it transforms the world and uses the material from which the old world's elegant edifices were constituted as the building blocks of the new. The world, created in the films of Jan Švankmajer, is a new, transformed one, a world of alternatives made real with the force of imagination.

Švankmajer's work is a body of miraculous compositions, which act on the viewer, either as a menace in the case of an outsider, or as a stimulant in the case of an initiate.

\section{Bibliography}

ALOQUIE, Ferdinand. 1965. The Philosophy of Surrealism. Ann Arbor: The University of Michigan Press, 1965.

CONCANNON, Phil. 2012. Jan Švankmajer [online]. Little White Lies: London, TCO London, 2012 (06-27) [accessed on Aug. 10 ${ }^{\text {th }}, 2014$ ]. Available on line at $<$ http://www.littlewhitelies. co.uk/features/articles/jan-svankmajer-2-20800>.

DONALD, James (ed.). 1989. Fantasy and the Cinema. London: BFI, 1989.

EFFENBERGER, Vratislav. 1989. Švankmajer on the Fall of the House of Usher. Transl. by Gaby

Dowdell. Afterimage 13 (1987): 33-7.

FOSTER, Hal. 1993. Compulsive Beauty. London: MIT Press, 1993.

HAMES, Peter (ed.). 1995. Dark Alchemy, The Films of Jan Švankmajer. Westport, Connecticut: Praeger Publishers, 1995.

HAMES, Peter. 1995. Interview with Jan Švankmajer. In Peter Hames (ed.). Dark Alchemy: The Films of Jan Švankmajer. Westport, Connecticut: Praeger Publishers, 1995: 96-118.

HAUSER, Arnold. 1986. Mannerism: The Crisis of the Renaissance and the Origin of Modern Art. Cambridge, Mass: Belknap Press of Harvard University Press, 1986.

KRÁL, Petr. 1987. Questions to Jan Švankmajer. Transl. by Gil McGreal. Afterimage 13 (1987): 22-32.

NORTH, Dan. 2009. The Last Trick [Online], [accessed on May $15^{\text {th }}, 2015$ ]. Available on line at $<$ https://drnorth.wordpress.com/2009/03/25/the-last-trick-jan-svankmajer-1964/> 
O'PRAY, Michael. 1988. Punch and Judy. Monthly Film Bulletin 55.659 (December 1988): 378.

STAFFORD, Mark and Virginie SELAVY. 2011. Interview with Jan Švankmajer [online] Electric Sheep Magazine: London, Strange Attractor, 2011 (06-14) [accessed on August 2 ${ }^{\text {nd }}, 2014$ ]. Available on line at: <http://www.electricsheepmagazine.co.uk/features/2011/06/14/interview-with-jan352 vankmajer/>

STRICK, Philip. 1986. The Last Trick. Monthly Film Bulletin 53.630 (1986): 223.

WELLS, Paul. 1999. Body Consciousness in the Films of Jan Švankmajer. In Jayne Pilling (ed.). A Reader in Animation Studies. London: John Libbey Cinema and Animation, 1999: 187.

\section{Summary}

This article explores the relation of Jan Švankmajer with the Czech puppet tradition, viewing his puppetry through a Surrealist prism and investigating the role of puppets in his work, as simultaneously inert objects and animated creatures that cross the dichotomous line between life and death, thereby raising questions in relation to human nature and identity. Jan Švankmajer is a leading Czech filmmaker and artist and a self-proclaimed militant surrealist. His work is characterised by a diversity of means and techniques, these include: live-action, puppets, clay modelling, traditional drawn animation, object collage, stop-frame special effects and stop-motion animation. Švankmajer's fascination with the corporeality of an animated entity has been developed through a deep and strong affinity with traditional Czech theatre. His own professional background in the puppet theatres of Prague, the Theatre of Masks, the Black Theatre and the Laterna Magika Puppet Theatre has significantly influenced his work. Švankmajer's work is the bearer of a magic function, revealing the marvellous through mystification. Švankmajer, like the alchemists of old, is continually distilling the water of his experiences so that through this process, the heavy water of knowledge, essential for the transmutation of life, begins to flow.

\section{Keywords}

Jan Švankmajer, Czech animation, Czech animated film, Czech puppet theatre, uncanny, Surrealism

DOI: $10.5817 /$ TY2015-2-8

Georgia Chryssouli (geochryss@yahoo.gr) is currently completing her PhD in Art History and Theory at the University of Essex (UK) with a thesis with the working title 'Jan Švankmajer, the Alchemist of the Surreal and his Cabinet of Curiosities'. At the University of Essex she also studied Modern Art and Theory and wrote a MA thesis on 'Art and Propaganda: The Aesthetisisation of Politics and the Fate of the Avant-Garde in National Socialist Germany'. She had formerly studied History, Archaeology and History of Art at the University of Athens and trained at the University of Paris and in the Archaeological Society of Athens. She has served as a curator, archaeologist and lecturer in archaeology and history of art and film in Greece and in the UK. 